\title{
SELECTED ASPECTS OF TINY VETCH [Vicia hirsuta (L.) GRAY S.F.] SEED ECOLOGY: GENERATIVE REPRODUCTION AND EFFECTS OF SEED MATURITY AND SEED STORAGE ON SEED GERMINATION
}

\author{
Magdalena Kucewicz, Katarzyna Maćkiewicz, Anna Źróbek-Sokolnik
}

\author{
Uniwersity of Warmia and Mazury, Department of Botany and Nature Protection, Plac Łódzki 1, 10-718 Olsztyn, Poland \\ e-mail: magdo@moskit.uwm.edu.pl
}

Received: 5.09 .2009

\section{Abstract}

Vicia hirsuta (L.) Gray S.F. (tiny vetch) is a common and persistent segetal weed. Tiny vetch seeds and pods reach different stages of maturity during the crop harvest season. Some seeds that mature before cereal harvest are shed in the field and deposited in the soil seed bank, while others become incorporated into seed material.

The objective of this study was to describe selected aspects of tiny vetch seed ecology: to determine the rate of individual reproduction of vetch plants growing in winter and spring grain crops and to evaluate the germination of seeds at different stages of maturity, subject to storage conditions.

The seeds and pods of $V$. hirsuta were sorted according to their development stages at harvest and divided into two groups. The first group was stored under laboratory conditions for two months. In the autumn of the same year, the seeds were subjected to germination tests. The remaining seeds were stored in a storeroom, and were planted in soil in the spring. The germination rate was evaluated after 8 months of storage.

Potential productivity (developed pods and flowers, fruit buds) was higher in plants fruiting in winter wheat than in spring barley. Vetch plants produced around $17-26 \%$ more pods (including cracked, mature, greenish-brown and green pods) and around $25 \%$ less buds in winter wheat than in spring barley.

Immature seeds were characterized by the highest germination capacity. Following storage under laboratory conditions and stratification in soil, mature seeds germinated at a rate of several percent. After storage in a storeroom, seeds at all three development stages broke dormancy at a rate of 72$75 \%$. The high germination power of tiny vetch seeds stored in a storeroom indicates that this plant can be classified as an obligatory speirochoric weed species.

Key words: Vicia hirsuta, tiny vetch, germination, seed maturation, storage, generative reproduction

\section{INTRODUCTION}

The segetal species of the wild-growing Vicia hirsuta (L.) Gray S.F. (tiny vetch) are semelparous plants that rely exclusively on generative reproduction. Seeds are the reproductive unit in tiny vetch. Mature seeds are easily shed by dry, cracked pods. According to K o r n a ś (1972), the released generative diasporas of tiny vetch spread by autochory (ballochory and barochory) and anthropochory, mainly speirochory with the sowing of mostly grain crops. In the crop harvest season, the seeds and pods of tiny vetch reach different stages of maturity. Some of the seeds that mature before cereal harvest are shed in the field and deposited in the soil seed bank. The remaining seeds are collected with the crops, i.e. cereal grain.

Most species of Fabaceae have an impermeable seed coat that imposes a physical exogenous dormancy (B a skin and B a skin, 1998; V a n A s s che etal. 2003). This family is dominated by species producing hard seeds, although certain species rarely grow them (Grzesiuk and Kulka, 1981). Hard seeds are a form of seed dormancy which is defined by ISTA (1985) as seeds which remain hard at the end of the prescribed test period due to seed coat impermeability to water. Many authors suggest that the ability to produce hard seeds is generally a hereditary trait (B a s k i n and B a skin, 1998; Grzesiuk and Kulka, 1981; R a m s a y, 1997).

From the biological point of view, the formation of seeds with water-impermeable coats is beneficial for the given species. Hard seeds are marked by higher viability and the ability to germinate after different dormancy periods. Those traits contribute to the preservation of certain wild plant species ( Grzesiuk and Kulka, 1981).

Research studies indicate that legume seeds become able to germinate at a specific development stage. It has been demonstrated ( $\mathrm{Cr}$ ista u do et al. 2008; Grzesiuk and $\mathrm{Kulka}, 1981$ ) that legume seed dormancy is a function of maturity. Seeds collected during early stages of development germinated 
relatively well, after which signs of dormancy were clearly manifested. Dormancy is usually deepest at full maturity (Grzesiuk and Kulka, 1981). In a different study, germination increased with seed maturity (e.g. Gre st a et al. 2007; S a m a r a h, 2005; S a m a rah and Abu-Yahya, 2008).

Weed seeds are stored with seed material until the spring. The conditions under which seeds are stored after harvest affect the dormancy of both field crop seeds and weed seeds. Desiccation and pre-chilling were shown to have an effect on the germination of seeds harvested at different maturity stages ( $\mathrm{S}$ a m a $\mathrm{rah}$ et al. , 2003; $\mathrm{S} \mathrm{a} \mathrm{m}$ a rah and $\mathrm{Mu} 11 \mathrm{e} n$, 2004). Air-drying and pre-chilling were suggested methods for improving the germination of immature seeds in some crops (B e w ley and B la ck, 1994; D a s g u p t a et al. 1982; R a s y a d et al. 1990). Literature data concerning the effect of maturity stage and storage conditions on the germination and dormancy of wild plant seeds are scant (Kucewicz and Hołdyński, 2003).

The objective of this study was to describe selected aspects of tiny vetch seed ecology: to compare the rate of individual reproduction of vetch plants growing in winter and spring grain crops, to evaluate the germination rate subject to the morphological diversity and maturity of seeds upon harvest, and to determine the effect of storage conditions on seed germination.

\section{MATERIALS AND METHODS}

\section{The species}

Vicia hirsuta (L.) S. F. Gray (tiny vetch) is an annual plant found in nearly all of Europe (T u t in , 1968). In Poland tiny vetch is a common and persistent segetal weed species (Hołdyński et al. 1986; Korniak, 1992).

\section{Pod and seed collection and storage}

Vicia hirsuta seeds were collected from the populations growing in winter and spring grain crops in north-eastern Poland (Tomaszkowo, Warmia and Mazury Region) in July and August 2001. The seeds were removed from pods by hand and separated into 3 groups, according to the development stages of pods and seeds. The pod and seed development stages were determined and described based on pod and seed color. Pods and seeds were classified as follows: 1) green seed/pod (G); 2) greenish-brown seed/pod (GB); 3) brown seed/pod (B), fully mature seeds. The description of maturity stages is shown in Table 1 . Seeds at each development stage were divided into two groups. The first group was dry-stored in paper bags under laboratory conditions at ambient temperature $\left(19 \pm 2^{\circ} \mathrm{C}\right)$ and RH (relative humidity) $35-45 \%$ for 2 months. In the autumn of the same year, seeds were subjected to germination tests. The remaining seeds were stored until spring, as follows: under laboratory conditions, in paper bags; in a storeroom at $3-8^{\circ} \mathrm{C}$ and $\mathrm{RH} 35-$ $45 \%$ (dry-prechilling); buried outside in nylon bags, at a depth of $7 \mathrm{~cm}$. The germination rate was evaluated after 8 months of storage.

\section{Germination test}

Seeds were placed in Petri dishes on two layers of filter paper moistened with $10 \mathrm{ml}$ of distilled water, and were incubated at $20 \pm 1^{\circ} \mathrm{C}$ in the dark. Prior to the germination test, stored seeds were surface sterilized with the fungicide Pimafucin. For each treatment, five replicates of 50 seeds were used. Seeds were considered to be germinated with the emergence of the radicle. The number of germinated seeds was counted at 4 , 10, 14 and 21 days after planting. Germination speed was estimated by calculating the germination rate index (GRI) as described by Mag u ire (1962) using the following formula:

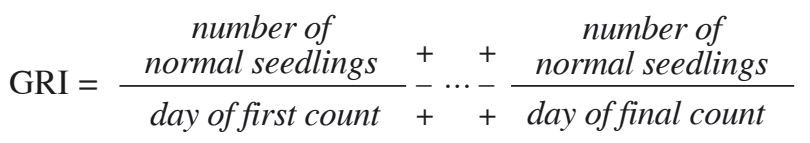

The final percentage of germinated seeds was calculated for 21 days following seed sowing.

The results are presented as means of the germination percentages obtained in five replicates $\pm \mathrm{SE}$ of the mean.

\section{Fresh weight, dry weight and seed moisture content determination}

At each development stage, five replicates of 100 seeds were randomly taken from the harvested seeds to measure fresh weigh (FW), dry weight (DW) and percentage seed water content (WC). The fresh weight of seeds was recorded immediately after separation from the pods. Seed samples were dried in the oven at $103^{\circ} \mathrm{C}$ for 24 hours and the dry weight of seeds was recorded to determine seed moisture content (\%) on wet weight basis.

\section{Generative reproduction}

In the pre-harvest period, 50 individuals were randomly selected from four populations infesting winter wheat and from three spring barley populations in the area of Tomaszkowo (Warmia and Mazury Region). The number of flowers, setting pods and pods at different stages of development were determined for each individual (their total number was described as potential productivity). Actual productivity was identified as the part of generative reproduction excluding setting pods and flowers. Individual productivity was determined based on the fixed number of seeds per pod (2). 
Table 1

Description of Vicia hirsuta pods and seeds at three development stages

\begin{tabular}{lcc}
\hline \multicolumn{1}{c}{ Stages of maturity } & Pod description & Seed description \\
\hline Green $(\mathrm{G})$ & Green, flat, hairy & $\begin{array}{c}\text { Green, soft, flat, lightly } \\
\text { wrinkled when dried }\end{array}$ \\
Greenish-brown (GB) & $\begin{array}{c}\text { Greenish-brown, filled, with clearly } \\
\text { visible seeds, hairy }\end{array}$ & $\begin{array}{c}\text { Green, speckled with brown } \\
\text { spots, filled }\end{array}$ \\
Brown (B) & Dark brown to black, dry, hairy & $\begin{array}{c}\text { Beige to brownish, with } \\
\text { numerous brown spots, hard }\end{array}$ \\
\hline
\end{tabular}

\section{RESULTS AND DISCUSSION}

\section{Generative reproduction}

The tiny vetch's longer life cycle in winter wheat resulted in higher total actual productivity and potential productivity in comparison with its reproductive output in spring barley (Fig. 1). The actual productivity was higher in plants fruiting in winter wheat than in spring barley, and it amounted to 173 pods (346 seeds) and 128 pods (256 seeds), respectively. Potential productivity which, in addition to developed pods, accounted also for flowers and fruit buds, reached an average of 178 pods (356 seeds) in winter wheat and 134 pods (268 seeds) in spring barley. Vetch plants produced around $17-26 \%$ more pods (including cracked, mature, greenish-brown and green pods) and around $25 \%$ less buds in winter wheat than in spring barley. In this study, the individual productivity of tiny vetch was similar to the results noted by D ob r o c h o tow (1961), Wehsarg (1961) and Korsmo (1930), but it was much below the findings of $\mathrm{Malicki}$ and Kwiecińska (1999). The generative reproduction rate of tiny vetch in winter and spring crops was investigated by Pawłowski (1966). The values noted in populations infesting winter wheat were similar, while those regarding spring barley were lower than the findings of this study. Vetch is characterized by a much higher productive potential than indicated by the studies of arable crops. Its generative reproduction rate in barren land was more than fourfold higher (M a j d a et al. 2007) than in crop fields. Such high differences are explained by the fact that generative reproduction is a species-specific character which is modified by environmental factors ( $\mathrm{F} \mathrm{a} \mathrm{li} \mathrm{n} \mathrm{s} \mathrm{k} \mathrm{a}$, 1977; K w i e cińs k a - P o p pe, 2006; M a li cki Kw i e cińska, 1999; P a w łowski et al. 1970).

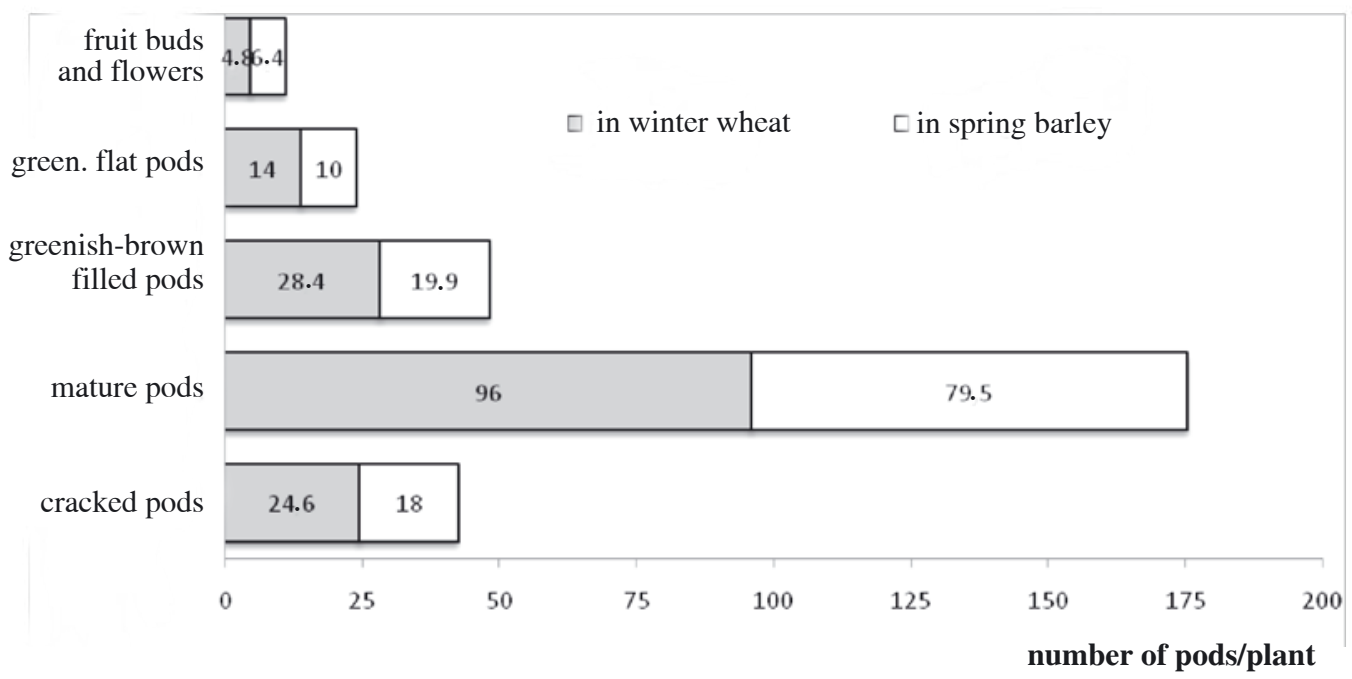

Fig. 1. Comparison of the rate of individual reproduction (number of pods/plant) of Vicia hirsuta plants growing in winter and spring grain crops 


\section{Fresh weight and moisture content}

Fresh weight (100 seeds) varied subject to the development stage reached by seeds at harvest (Fig. 2 ). The development and maturing of diaspores were accompanied by an increase in fresh weight (FW) and dry weight (DW) as well as by a decrease in seed moisture content (SMC). Seeds in phase G were characterized by the lowest weight $(0.35 \mathrm{~g})$ and the highest moisture content $(81 \%)$. In mature seeds (B), weight increased more than twofold $(0.74 \mathrm{~g})$, while moisture content dropped to approximately $15 \%$ (Fig. 1). Moisture content is the key factor responsible for the life processes of plants and seeds (B a illy and al. 2003; H e g a r t y , 1978). Significant diaspore dehydration at the final maturing stages supports and, in some cases, enforces dormancy (Egli and TeKrony, 1997; Kopcewicz and Lewak 2007).

\section{Seed germination}

The storage of seeds under laboratory conditions, in a dry environment at a high and constant temperature, did not support germination. In the autumn, two months after harvest, the germination rate index of laboratory-stored seeds in phases GB and B was largely inhibited (at 3\% and 4\%, respectively), and these seeds were in a deeper state of dormancy than undeveloped seeds $(G)$ which germinated at a rate of $67 \%$. The germination parameters did not improve after 8 months of storage. Seeds in phases GB and B were still in dormancy, the dormancy of seeds in phase $\mathrm{G}$ was deepened and their germination rate fell to $42 \%$. Storeroom conditions had a beneficial effect on SG and GRI, and seeds at all three development stages broke dormancy at a rate of $72-75 \%$. Germination was poor after seeds had been removed from soil. The germination rate index of seeds at stages GB and B was $4-1 \%$, only immature seeds $(\mathrm{G})$ germinated at a rate of $27 \%$ (Fig. 3).

The method and time of seed storage affect the depth of dormancy. The storage of Vicia hirsuta seeds in a dry laboratory environment at a temperature of around $20^{\circ} \mathrm{C}$ did not support germination. Seeds in phases GB and B were in a state of deep dormancy after 2 and 8 months of storage. The germination rates were lower after 8 months than after 2 months. $\mathrm{V}$ a n A s s che et al. (2003) reported similar results in a study of Vicia hirsuta seeds. After two months of storage under laboratory conditions (at around $20^{\circ} \mathrm{C}$ ), the germination rates did not exceed $1.7 \%$ at any of the temperatures studied $\left(30,23,10\right.$ and $20 / 10^{\circ} \mathrm{C}$ ). Low germination rates were also noted in respect of Vicia angustifolia seeds after 6 months of incubation at a constant temperature $\left(15,25^{\circ}\right)$ ( $\mathrm{Y}$ u r a and $\mathrm{H}$ a y a k a w a , 2000). The above germination rates of seeds stored at a high and constant temperature are consist- ent with the findings of $\mathrm{Grzesiuk}$ and $\mathrm{Kulka}$ (1981). As noted by the above authors, warm and dry storage conditions deepen dormancy, and storage under high temperatures favors the transformation from permeable to hard seeds (O w e $n, 1956)$. These findings do not constitute a general rule, however, as the seeds of other Fabaceae species responded differently: for example, newly-harvested Vicia ervilla seeds produced higher germination rates at the immature stage than at other development stages ( $\mathrm{S} \mathrm{a} \mathrm{marah}$ et al. 2003). When stored for 20 days at $20^{\circ} \mathrm{C}$ (air-dried), immature seeds did not germinate, while mature seeds germinated at a much higher rate. Air-dried seeds had a higher germination rate index than fresh seeds $(\mathrm{S} \mathrm{a}$ $\mathrm{m}$ a ra h et al. 2003). Vicia sativa seeds collected in phases BS and SF (undeveloped seeds) and stored at ambient conditions were characterized by low germination rates and deeper dormancy than seeds harvested in phases GY, Y and B (mature seeds). The reduction in germination of depodded dried immature seeds was mainly due to the presence of dead and dormant seeds (S a $\mathrm{m}$ a r a h, 2005). Storage time induced a softening effect, even though seeds of Scorpiurus subvillosus were stored under laboratory conditions ( $\mathrm{Gres}$ s a et al. 2007)

Storeroom conditions $\left(5-8^{\circ} \mathrm{C}\right)$ offered the most supporting environment for breaking the dormancy of $V$. hirsuta seeds. Seeds at all three maturity stages germinated at a rate of $72-75 \%$. This response was validated by B r o n i e w s ki (1961) who argued that low temperatures, even below $0^{\circ} \mathrm{C}$, stimulated dormancy break and the germination of seeds of wild-grown plants. It should be noted, however, that the contribution of low temperatures to dormancy break and the germination of tiny vetch seeds was not confirmed by other authors. In an experiment performed by Van A ssche et al. (2003), hard Vicia hirsuta seeds chilled at $5^{\circ} \mathrm{C}$ for 8 weeks and tested at 23 , $10,20 / 10,15 / 6^{\circ} \mathrm{C}$ germinated at a rate of $0.3-1.2 \%$. Seeds kept at low temperatures for 8 weeks and then exposed to a temperature of $20^{\circ} \mathrm{C}$ were unable to germinate. The seeds of Vicia angustifolia, a winter annual plant, yielded a very low germination rate index when, after storage at low temperatures $\left(4,15^{\circ} \mathrm{C}\right)$ for several months, they were transferred to $15^{\circ} \mathrm{C}$ and $5 / 25^{\circ}$ (Y ura and Hayakawa, 2000). Similar results to those noted in this study were noted with respect to Vicia ervilla seeds ( $\mathrm{S}$ a $\mathrm{m}$ a r a h et al. 2003). When dry-prechilled at $5^{\circ} \mathrm{C}$ for 8 days, seeds at stages YP and BP (mature seeds) germinated at a higher rate than fresh seeds (83\% and 99\%, respectively), while immature seeds were characterized by similar germination rates as before prechilling, or only slightly higher. 


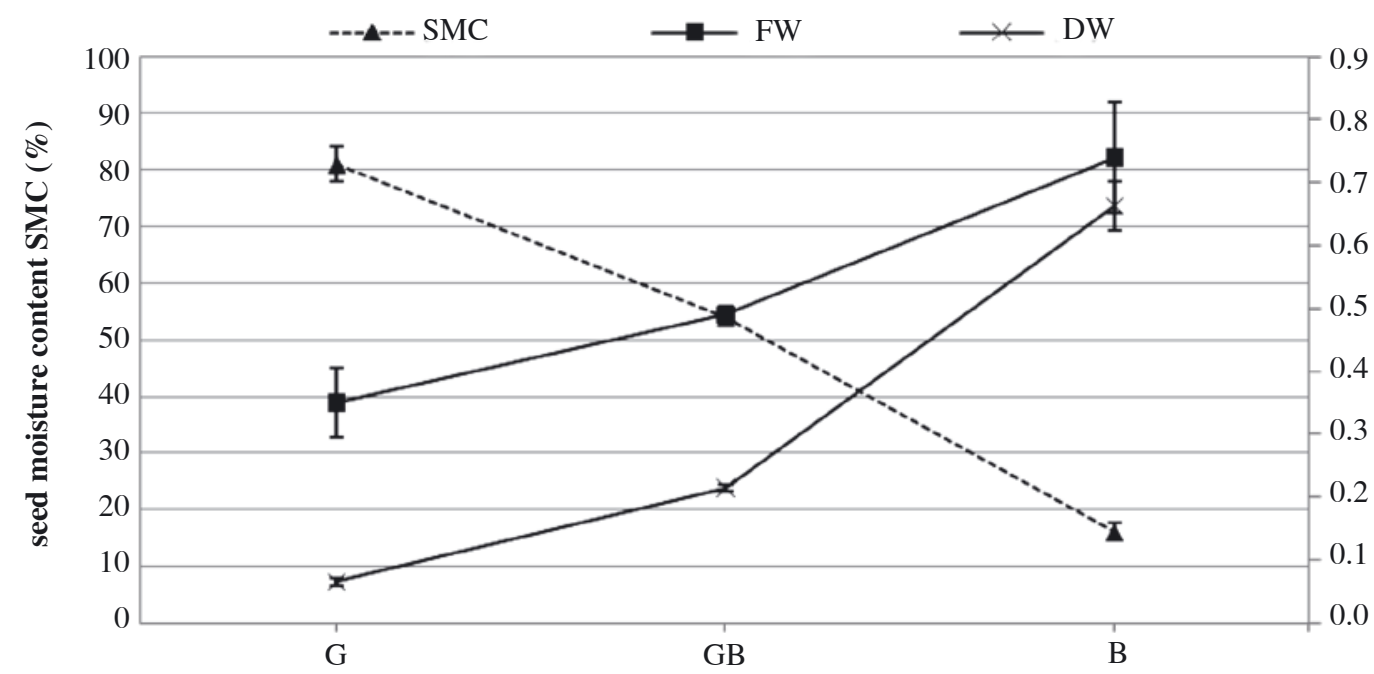

Fig. 2. Seed moisture content (SMC), fresh weight (FW) and dry weight (DW) of Vicia hirsuta seeds harvested at three developmental stages $(\mathrm{G}, \mathrm{GB}, \mathrm{B})$. Vertical bars represent $\mathrm{SE}$

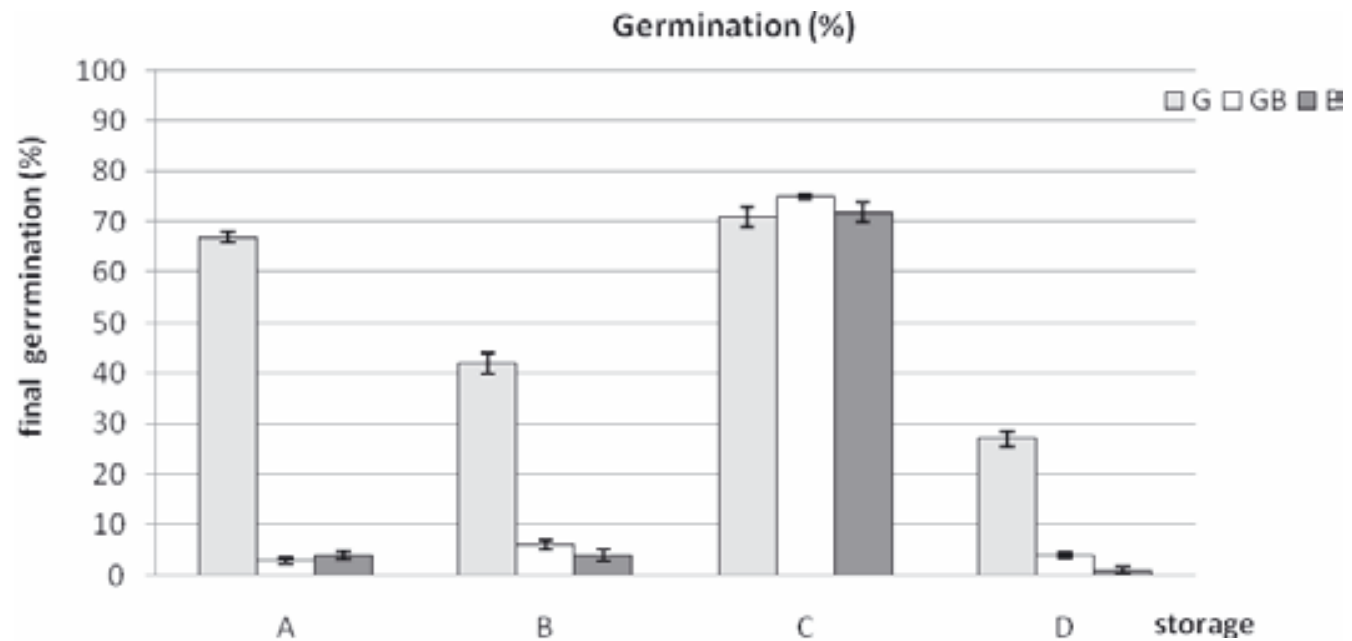

Germination rate index

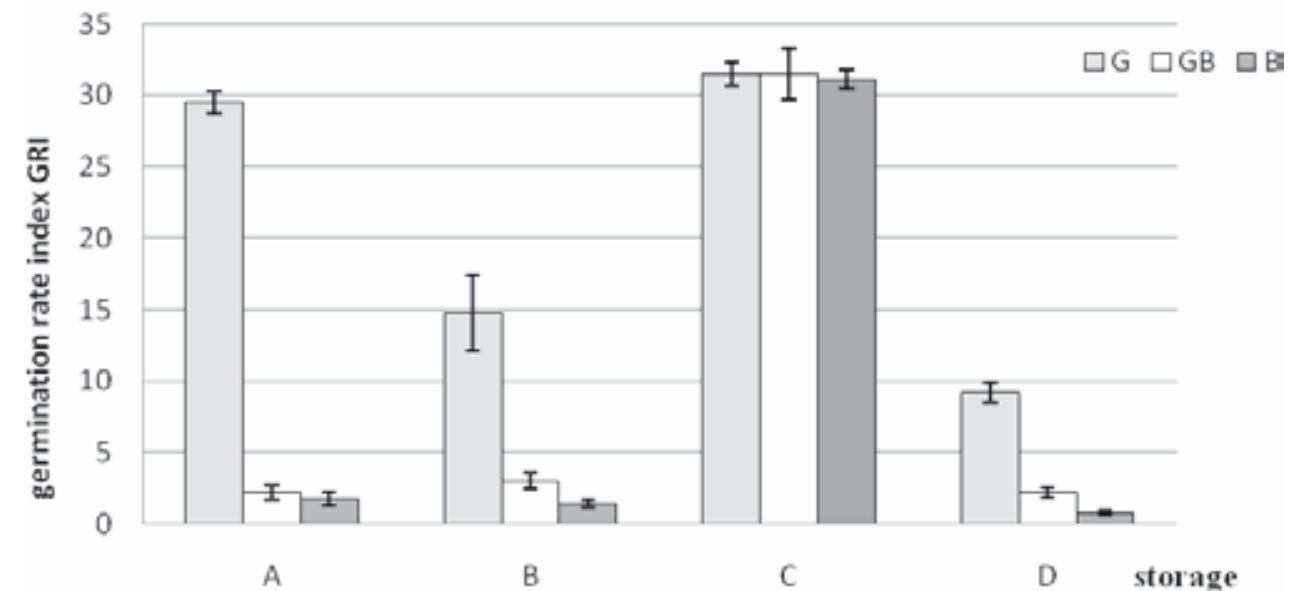

Fig. 3. Effect of seed storage on final germination percentages and germination rate index (GRI) of Vicia hirsuta seeds at three developmental stages (G, GB, B). Treatments:

A - laboratory, 2 mo, test - autumn; B - laboratory, 8 mo, test - spring; $\mathrm{C}$ - storeroom, $8 \mathrm{mo}$, test - spring; D - buried in the soil, 8 mo, test - spring. Vertical bars represent SE 
The results of this experiment as well as published data suggest that the dormancy of tiny vetch seeds is most probably broken not only by low temperatures, but also by an adequate moisture content and good aeration (B roniewski, 1961; Li ty ński, 1982). Storeroom conditions met the above requirements. The ability of pre-chilling to release dormancy was probably due to various metabolisms that occur during these treatments, including an increase in the levels and responsiveness of endogenous gibberellins (Hil h or s t and Kars se n, 1992), and a substantial decrease in the ABA levels (B e w le y and B lack, 1982).

According to Kornaś (1972), the generative diaspores of Vicia hirsuta spread not only by autochory (ballochory and barochory), but also by anthropochory with the sowing of crop plants (speirochory). K o r $\mathrm{n}$ a s $(1972 ; 1987)$ classifies vetch as a facultative speirochoric weed which does not demonstrate specific morphological and biological properties supporting this type of propagation. The results of this study indicate that tiny vetch can be classified as an obligatory speirochoric weed. When stored in a storeroom, the seeds of the investigated species are marked by high germination capacity, implying that they are well adapted to spreading by speirochory in field ecosystems.

The germination rate index of tiny vetch seeds removed from soil was low, at 4-1\% at the GB stage, and $27 \%$ at the immature $(\mathrm{G})$ stage. These findings are similar to the results noted by $\mathrm{V}$ a n A s s che et al. (2003). In their study, Vicia hirsuta seeds buried in the ground for 2 years were excavated at monthly intervals and subjected to germination tests. A seasonal germination pattern was not noted and the analyzed seeds germinated at a very low rate $(<1 \%)$ in every month of the study.

The most probable reason for inhibited germination of mature seeds is the induction of dormancy. Mature and less mature seeds (B, GB) show dormancy due to their hard impermeable seed coat that prevents water absorption and gaseous exchange, which induces deep dormancy according to many authors (B a s k i n and B a skin, 1998; Egley, 1995). The observed response of tiny vetch seeds at stages GB and $\mathrm{B}$ has been validated by $\mathrm{Cr}$ i s t a u d o et al. (2008), Gr ze s i u k and Kulka (1981) who noted that the dormancy of legume seeds is induced as late as at the end of maturation, and the depth of dormancy is a function of maturity. According to other authors, seed hardness is observed in various Fabaceae species at different stages of development, but the same argument is used to explain the decrease in seed hardness. The results of other studies indicate that the germination rate index of Vigna radiata, Vicia sativa, Cicer arietinum and Glycine seeds increased with maturity, reaching the maximum value at the physiological maturity stage (H a mid et al. 1988; Mile s et al. 1988; $\mathrm{S}$ a m a r a h and A bu - Y a h y a, 2008) or at the stage directly preceding physiological maturity (S a m a r a h, 2005).

\section{CONCLUSIONS}

1. The seeds of tiny vetch reach different stages of maturity before and upon crop harvest. Some seeds are deposited in the soil seed bank, while others find their way to the seed material which is stored until sowing in the spring. Harvest time determines the rate of actual productivity of tiny vetch seeds, which is higher for vetch plants infesting winter crops than spring crops.

2. Tiny vetch seeds at different maturity stages $(G$, $\mathrm{GB}, \mathrm{B})$ were stored under various conditions. In each group of the investigated seeds, the highest germination rate index was reported for immature seeds $(G)$. Seeds at maturity stages GB and B were dormant seeds with germination rates of several percent. Their dormancy was not broken after longterm storage under laboratory conditions or stratification in the soil in the winter season. Storage in a cool and dry storeroom environment was most conducive to breaking the dormancy of seeds at all development stages.

3. The wild-growing, segetal tiny vetch maintains a constant seed bank population in soil. The part of the population found in seed material (stored in a storeroom) successfully germinates in the agrocenosis when sown together with crop plants. The ease with which tiny vetch seeds germinate after storage in a storeroom implies that they are well adapted to spreading by speirochory in field ecosystems. In view of its biological adaptation for agricultural treatment and post-harvest conditions, tiny vetch may be classified as an obligatory speirochoric species.

\section{REFERENCES}

Bailly C., Walters C., Côme D., Corbineau F. 2003. Seed water status as related to storability and dormancy. International Workshop on Applied Seed Biology "New Development in Seed Quality Improvement", Łódź (Poland) 23-25 October 2003: 19-20.

B a s k in J. M., B a s k in C.C. 1998. Seeds. Ecology, biogeography and evolution of dormancy and germination. New York: Academic Press.

B ew le y J. D., B l a ck M. 1982. Physiology and Biochemistry of Seeds. Springer-Verlag, Berlin.

B ron iew ski S. 1961. Stan spoczynkowy nasion. / Seed dormancy. Biul. IHAR Kraków, 6: 103-107.

Cristaudo A., Gresta F., Avola G., Miano V. 2008. Germination capability of immature seeds of Lotus or- 
nithopodioides L. and Scorpiurus subvillosus L. Proceedings of the $12^{\text {th }}$ Meeting of the FAO-CIHEAM SubNetwork on Mediterranean Pastures And Fodder Crops, Elvas (Portugal) 9-12 April 2008: 289-292

Dasgupta J., Bawley J. D., Yeung E. C. 1982. Dessication-tolerant and dessication-intolerant stages during development and germination of Phaseolus vulgaris seeds. J. Exp. Bot.33:1045-1057.

Dobroch otow W. N. 1961. Semena sornych rastienij. Sielchozgiz, Moskwa.

Egley G. H. 1995. Seed germination in soil: Dormancy cycle. p. 529-543. In "Seed development and germination" Kigel J. and Galili G. (eds). Marcel Dekker, Inc. New York.

Egli D. B., TeKrony D. M. 1997. Species differences in seed water status during seed maturation and germination. Seed Sci. Res. 7: 3-12.

Falińska K. 1977. Strategia i taktyka reprodukcyjna populacji roślinnych. / Reproduction strategy and tactics of plant populations. Wiad. Ekol. 23 (3): 229-257.

Gresta F., Avola G., Abbate V. 2007. Germination ecology of Scorpiurus subvillosus L. seeds: the role of temperature and storage time. Plant Ecol. 190: 123-130.

Grzesiuk S. 1967. Zagadnienia spoczynku nasion. / Aspects of seed dormancy. Biul. IHAR, 1-2: 15-22.

Grzesiuk S., Kulka K. 1981. Fizjologia i biochemia nasion. / Państwowe Wydawnictwo Rolnicze i Leśne, Warszawa.

Hamid A., Hashem A., Hamid A., Ahad Miah M. A., $\mathrm{Nag}$ B. L. 1995. Seed development, quality, maturity, synchrony and yield of selected mungbean genotypes. Seed Sci Technol. 23: 761-770.

Hegarty T. W. 1978. The physiology of seed hydration and dehydration, and the relation between water stress and the control of germination: a review. Plant, Cell Envir. 1: 101-119.

Hilhorst H. W. M., Karssen C. M. 1992. Seed dormancy and germination: the role of abscisic acid and gibberellins and the importance of hormone mutants. Plant Growth Regul. 11: 225-238.

Hołdyński Cz. 1986. Rozmieszczenie niektórych interesujących gatunków segetalnych na Pojezierzu Iławskim. / Distribution of some interesting segetal species in Iława Lakeland. Acta Acad. Agricult. Techn. Olst. Agric. 43: 21-29.

I S T A (International Seed Testing Association) 1985. Rules for seed testing. Seed Sci Technol. 13: 300-520.

Ko p cew i c z J., Lew ak S. 2007. Fizjologia roślin. Państwowe Wydawnictwa Naukowe, Warszawa.

Kornaś J. 1972. Rozmieszczenie i ekologia rozsiewania się chwastów polnych w Gorcach. / Distribution and dispersal ecology of weeds in segetal plant communities in the Gorce Mts. (Polish Western Carpathians). Acta Agrobot. 25 (1): 1-67.

Kornaś J. 1987. Chwasty polne rozprzestrzeniające się z materiałem siewnym. Specjalizacja ekologiczna i procesy wymierania. / Speirochoric field weeds: from ecological specialization to extinction. Zesz. Nauk. AR w Krakowie, 216 (19): 23-26.

Korniak T. 1992. Flora segetalna północno-wschodniej polski, jej przestrzenne zróżnicowanie i współczesna przemiany./ Segetal flora of north-eastern Poland, its spatial differentiation and current changes. Acta Acad. Agricult. Techn. Olst. Agricultura, 53: 1-76.

Kor s m o E. 1930. Unkräuter im Ackerbau der Neuzeit., Berlin, J. Springer.

Kucewicz M., Hołdyński C. 2003. Germination of Matricaria maritima subsp. inodora (L.) Dostal (scentless mayweed) achenes depending on their maturity and position on mother plant. J. Plant Protection Res. 43 (2): 143-153.

Kw iec ińs k a - P op pe E. 2006. Plenność wybranych gatunków chwastów segetalnych na ciężkiej rędzinie czarnoziemnej. / Seed production of some segetal weed species on heavy chernozem rendzina. Acta Agroph. 8 (2): 441-448.

Li t y ń s k i M. 1982. Biologiczne podstawy nasiennictwa. Państwowe Wydawnictwo Naukowe, Warszawa.

Magu ire J. D. 1962. Speed of germination - aid in selection and evaluation for seedling emergence and vigor. Crop Sci, 2: 176-177.

Majd a J., B u c ze k J., Trą b a Cz. 2007. Plenność niektórych gatunków chwastów owocujących na odłogu./ Seed production of some weed species fruiting on fallows. Ann. UMCS Sect. E, LXII (2): 48-55

Malicki L., Kwiecińska E. 1999. Plenność pospolitych gatunków chwastów polnych na rędzinie. / Fertility of common arable weed species on rendzina soil. Fragm. Agronom. 3 (63): 97-109.

Miles D. F., TeKrony D. M., Egli D. B. 1988. Changes in viability, germination and respiration of freshly harvested soybean seed during development. Crop Sci. 28: 700-704.

Owen E. B. 1956. The storage of seeds for maintenance of viability. Bulletin 43. Commonwealth Bur. Pastures and Field Crops. Hurley, Berks, England.

Pawłowski F. 1966. Płodność, wysokość i krzewienie się niektórych gatunków chwastów w łanach roślin uprawnych na glebie lessowej. / Prolificacy, height and ability of producing shoots on some weed species growing among crop plants on loess soil. Ann. UMCS Lublin, Sect. E, 21 (9): 175-187.

Pawłowski F. 1970. Płodność chwastów w różnych siedliskach./ The prolificacy of weeds in various habitats. Ann. UMCS Lublin, Sect. E, 25 (5): 61-75.

R a m s a y G. 1997. Inheritance and linkage of a gene for testaimposed seed dormancy in faba bean (Vicia faba L.) . Plant Breed. 116: 287-289.

$\mathrm{S}$ a m a r a N N. H. 2005. Effect of drying methods on germination and dormancy of common vetch (Vicia sativa $\mathrm{L}$.) seed harvested at different maturity stages. Seed Sci Technol. 33 (3): 733-740. 
Samarah N. H., Abu-Yahya A. 2008. Effect of maturity stages of winter- and spring-sown chickpea (Cicer arietinum L.) on germination and vigour of the harvested seeds. Seed Sci Technol. 36 (1): 177-190.

S a m a rah N. H., A 11 at a ifeh N., Turk M., Tawaha A. R. 2003. Effect of maturity stage on germination and dormancy of fresh and air-dried seeds of bitter vetch (Vicia ervilia L.). New Zealand J. Agric. Res. 46: 347-354.

S a m a ra h N. H., Mulle n R. H. 2004. Effect of maturity stage on seed germination and vigour of common vetch (Vicia sativa L.). Seed Technol. 26 (1): 27-37.

Tut in T.G., Heywood V. H., Burges N.A., Moore D. M., Valentine D. H., Walters S., Webb D. A. 1968. Flora Europaea. Vol. 2. Rosaceae to Umbeliferae. Cambridge University Press.

Van Assche J. A., Debucquoy K. L. A., Rommens W. A. F. 2003. Seasonal cycles in the germination capacity of buried seeds of some Leguminosae (Fabaceae). New Phytol. 158: 315-323.

Wehs arg O. 1961. Chwasty polne. Państwowe Wyd. Rolnicze i Leśne: 336.

Yura H., Hayakawa M. 2000. Germination Responses of Seeds of Vicia angustifolia L. at Constant, Increased and Decreased Temperature. Nat. His. Res. 6 (1): 15-21.

\section{Wybrane aspekty ekologii nasion wyki drobnokwiatowej [Vicia hirsuta (L.) Gray F.S.]: reprodukcja generatywna oraz wpływ stopnia dojrzałości i warunków przechowywania na kiełkowanie nasion}

\section{Streszczenie}

Vicia hirsuta (L.) Gray S.F. (wyka drobnokwiatowa) jest pospolitym i uciążliwym chwastem segetalnym. W okresie zbioru rośliny uprawnej strąki i nasiona wyki uzyskują różny poziom dojrzałości. Część nasion, która dojrzewa przed sprzętem zbóż, podczas zbioru osypuje się na polu i wchodzi do glebowego banku nasion, pozostałe dostają się do materiału siewnego.

Celem badań było prześledzenie losów nasion wyki drobnokwiatowej: określenie poziomu reprodukcji osobniczej wyki rosnącej w zbożach ozimych i jarych oraz ocena kiełkowania nasion o różnym stopniu dojrzałości w zależności od warunków ich przechowywania.

Strąki i nasiona $V$. hirsuta posegregowano według osiągniętych w momencie zbioru faz rozwojowych, następnie podzielono je na dwie partie. Pierwszą $\mathrm{z}$ nich przechowano przez dwa miesiące $w$ warunkach laboratoryjnych, jesienią tego samego roku nasiona poddano testom kiełkowania. Pozostałe przechowano do wiosny w laboratorium, w warunkach magazynowych oraz zakopane w glebie. Po 8 miesiącach oceniono kiełkowanie.

Potencjalny wysiłek reprodukcyjny (wykształcone strąki, kwiaty i zawiązki owoców) był wyższy u roślin owocujących w pszenicy ozimej niż w jęczmieniu jarym. Rośliny wyki w pszenicy ozimej wytwarzały o ok. 17-26\% więcej strąków (w tym: pękniętych, dojrzałych, zielono brązowych i zielonych) niż w jęczmieniu jarym, jedynie zawiązków było o ok. $25 \%$ mniej.

Najwyższą zdolnością kiełkowania charakteryzowały się nasiona niedojrzałe. Nasiona dojrzałe, po przechowywaniu $w$ warunkach laboratoryjnych i po stratyfikacji w glebie kiełkowały na poziomie kilku procent. Po przechowaniu w warunkach magazynowych nasiona wszystkich faz przełamywały spoczynek na poziomie $72-75 \%$.

Łatwość, z jaką nasiona wyki drobnokwiatowej kiełkowały po przechowaniu w magazynie wskazuje, że można ją zaliczyć do speirochorów obligatoryjnych. 